\title{
Measurement of the NIF Gunite Shielding Composition and Implications for Neutron Activation and Worker Doses
}

\author{
J. F. Latkowski
}

This article was submitted to

$14^{\text {th }}$ Topical Meeting on the Technology of Fusion Energy

Park City, Utah

October 15-19, 2000

U.S. Department of Energy

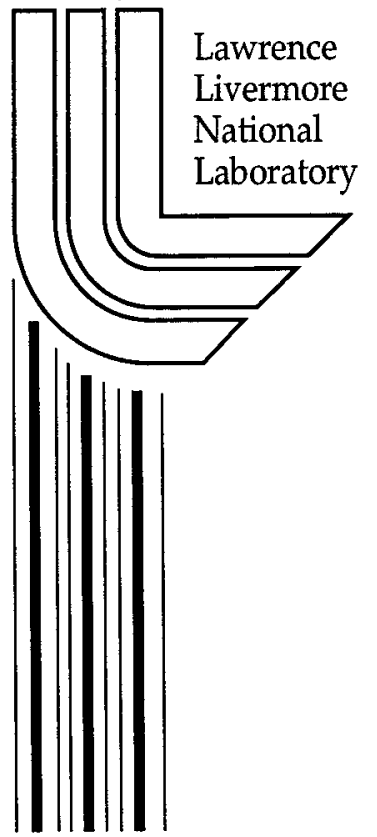

October 10, 2000 


\section{DISCLAIMER}

This document was prepared as an account of work sponsored by an agency of the United States Government. Neither the United States Government nor the University of California nor any of their employees, makes any warranty, express or implied, or assumes any legal liability or responsibility for the accuracy, completeness, or usefulness of any information, apparatus, product, or process disclosed, or represents that its use would not infringe privately owned rights. Reference herein to any specific commercial product, process, or service by trade name, trademark, manufacturer, or otherwise, does not necessarily constitute or imply its endorsement, recommendation, or favoring by the United States Government or the University of California. The views and opinions of authors expressed herein do not necessarily state or reflect those of the United States Government or the University of California, and shall not be used for advertising or product endorsement purposes.

This is a preprint of a paper intended for publication in a journal or proceedings. Since changes may be made before publication, this preprint is made available with the understanding that it will not be cited or reproduced without the permission of the author.

This report has been reproduced directly from the best available copy.

Available electronically at http://www.doc.gov/bridge

Available for a processing fee to U.S. Department of Energy

And its contractors in paper from

U.S. Department of Energy

Office of Scientific and Technical Information

P.O. Box 62

Oak Ridge, TN 37831-0062

Telephone: (865) 576-8401

Facsimile: (865) 576-5728

E-mail: reports@adonis.osti.gov

Available for the sale to the public from

U.S. Department of Commerce

National Technical Information Service

5285 Port Royal Road

Springfield, VA 22161

Telephone: (800) 553-6847

Facsimile: (703) 605-6900

E-mail: orders@ntis.fedworld.gov

Online ordering: http:/ / www.ntis.gov/ordering.htm

\section{OR}

Lawrence Livermore National Laboratory

Technical Information Department's Digital Library

http: / / www.llnl.gov/tid/Library.html 


\title{
Measurement of the NIF Gunite Shielding Composition and Implications for Neutron Activation and Worker Doses
}

\author{
J. F. Latkowski \\ Lawrence Livermore National Laboratory \\ P. O. Box 808, L-632, Livermore, CA 94551
}

\section{ABSTRACT}

In December 1999 and January 2000, a 40-cm-thick spherical shell of sprayable concrete ("gunite") was applied to the exterior surface of the National Ignition Facility (NIF) target chamber. Glow-discharge mass spectroscopy has been to determine the elemental composition of multiple gunite samples, which were collected at the time of application. These measured compositions are compared to the anticipated composition and both are used for neutron activation calculations. Contact dose rates are reported and implications for doses rates during operation and for the eventual facility decommissioning are discussed.

\section{INTRODUCTION}

The NIF will consist of 192 laser beams that will be directed to the center of a 10 -m-diameter target chamber. The target chamber is constructed of an aluminum alloy and is $10 \mathrm{~cm}$ thick. It sits upon a concrete and aluminum pedestal in the center of a $30 \mathrm{~m}$ diameter building that is approximately $35 \mathrm{~m}$ in height. If unchecked, neutron activation of the target chamber would result in unacceptably high doses rates during maintenance activities. To reduce these dose rates, the exterior surface of the target chamber has been coated with $40 \mathrm{~cm}$ of gunite shielding. The gunite shielding will absorb and attenuate decay gamma-rays emitted from the target chamber thereby reducing the exterior dose rate. The gunite also will reduce neutron fluxes to components outside the NIF target chamber, and thus, reduce activation of these ex-vessel components.

Naturally, the $200+$ tons of gunite will be exposed to significant neutron fluxes, and thus, it will also become activated. The detailed elemental composition is an important characteristic in the calculation of neutron activation and subsequent dose rates. In the present work, we discuss the measured compositions of collected gunite samples and evaluate the effect of the compositions upon neutron activation and residual dose rates in the vicinity of the target chamber.

\section{METHODS AND ASSUMPTIONS}

Application of the NIF gunite took place from December 15, 1999 to January 10, 2000. A sample was collected from each batch and compositions are averaged over samples from each particular day. Table I shows the chronology of the gunite application.

Table I. Chronology of the NIF gunite application

\begin{tabular}{clc}
\hline Date & \multicolumn{1}{c}{ Location description } & Thickness \\
\hline $12 / 15 / 99$ & Upper 40\% of sphere & $0-20 \mathrm{~cm}$ \\
$12 / 16 / 99$ & One-half of lower 60\% of sphere & $0-20 \mathrm{~cm}$ \\
$12 / 17 / 99$ & Remainder of lower 60\% of sphere & $0-20 \mathrm{~cm}$ \\
$12 / 23 / 99$ & Lowermost 40\% of sphere & $20-30 \mathrm{~cm}$ \\
$1 / 5 / 00$ & Upper 40\% of sphere & $20-40 \mathrm{~cm}$ \\
$1 / 6 / 00$ & Middle 20\% of sphere & $20-40 \mathrm{~cm}$ \\
$1 / 7 / 00$ & 20\% of sphere between middle & $30-40 \mathrm{~cm}$ \\
& section and lowest point & $30-40 \mathrm{~cm}$ \\
\hline
\end{tabular}

Analysis of the gunite samples began with crushing down to $<100 \mu \mathrm{m}$ particles. Crushing occurs between two tungsten plates. Tungsten contamination of the samples is not believed to be an issue due to the lack of tungsten observed in control samples.

Following crushing samples were tested using glow discharge mass spectroscopy (GDMS). GDMS provides fast, quantitative results. A $1 \mathrm{kV}$ argon plasma is used to sputter atoms off of the sample. These atoms diffuse into an ionization chamber, and they are accelerated to $8 \mathrm{kV}$. Finally, a magnetic section is used for mass analysis. Due to the testing procedure, GDMS testing does not provide a result for indium.

Neutron transport calculations have been completed with the TART Monte Carlo code.' The neutron spectrum was then used with the $\mathrm{ACAB} 98$ code in conjunction with FENDL/A-2.0 activation cross sections. $^{2-3}$ Activation calculations assume 10 years of NIF operation at $1200 \mathrm{MJ} /$ year. Each year consists of sixty shots each with $20 \mathrm{MJ}$ of fusion yield. Radiation cooling times are given as a function of time after a final, $20 \mathrm{MJ}$ yield. Results are presented in the form of contact dose rates. Contact dose rates take the calculated concentration (in $\mathrm{Bq} / \mathrm{m}^{3}$ ) of each radionuclide (calculated for a finite volume) and assume that they are present at the same concentration in a semi-infinite medium.

\section{GUNITE SPECIFICATION AND COMPOSITION}

The NIF gunite was specified following a survey of locally available aggregates, sands, and cements. It was 
found that a limestone aggregate typically had good properties along with low levels of impurities and a low aluminum content. This aggregate was used for the elevated slabs within the NIF Target Bay. For use in the gunite shielding, boric acid was added to the mix to enhance the capture of low-energy neutrons. Since the boric acid retards the set of the gunite, an accelerant was added at the application nozzle.

A test run of the gunite application process-the contractor needed to work out procedures for overhead application and for dealing with the addition of the accelerant-afforded the opportunity to test its composition. The aluminum content is a key indicator of the short-term dose rate due to the ${ }^{27} \mathrm{Al}(\mathrm{n}, \alpha)^{24} \mathrm{Na}$ reaction, which dominates. The first round of testing used an alternate aggregate, and a high aluminum content of $5.5 \%$ was observed. In the second round, the contractor switched back to the limestone aggregate and the aluminum content fell to only $3 \%$.

Elemental compositions were measured for eight samples-one from each day of gunite application. For each element, Table II gives the lowest, highest, and average concentrations among the eight samples.

Table II. Measured elemental compositions for the NIF gunite

\begin{tabular}{|c|c|c|c|c|c|c|c|}
\hline \multirow[b]{2}{*}{ Element } & \multicolumn{3}{|c|}{ Concentration (wppm) } & \multirow[b]{2}{*}{ Element } & \multicolumn{3}{|c|}{ Concentration (wppm) } \\
\hline & Minimum & Maximum & Average & & Minimum & Maximum & Average \\
\hline $\mathrm{H}$ & 116 & 649 & 259 & $\mathrm{Rh}$ & 0.02 & 0.83 & 0.20 \\
\hline $\mathrm{Li}$ & 3.11 & 31.8 & 15.1 & $\mathrm{Pd}$ & 0.48 & 6.01 & 3.32 \\
\hline $\mathrm{Be}$ & 0.27 & 0.99 & 0.63 & $\mathrm{Ag}$ & 1.00 & 3.49 & 2.31 \\
\hline $\mathrm{B}$ & 1460 & 1530 & 1490 & $\mathrm{Cd}$ & 0.28 & 1.16 & 0.64 \\
\hline $\mathrm{N}$ & 3.50 & 20.2 & 12.0 & Sn & 2.62 & 6.34 & 4.35 \\
\hline $\mathrm{O}$ & $55.2 \%$ & $59.7 \%$ & $57.9 \%$ & $\mathrm{Sb}$ & 0.83 & 5.59 & 2.05 \\
\hline $\mathrm{F}$ & 0.29 & 102 & 28.0 & $\mathrm{Te}$ & 1.16 & 5.39 & 2.43 \\
\hline $\mathrm{Na}$ & 5250 & 6530 & 5870 & I & 0.22 & 2.16 & 1.04 \\
\hline $\mathrm{Mg}$ & 5840 & 12600 & 8360 & $\mathrm{Cd}$ & 0.13 & 0.87 & 0.42 \\
\hline $\mathrm{Al}$ & $3.2 \%$ & $6.2 \%$ & $4.5 \%$ & $\mathrm{Ba}$ & 118 & 311 & 240 \\
\hline $\mathrm{Si}$ & $20.6 \%$ & $25.9 \%$ & $23.4 \%$ & $\mathrm{La}$ & 1.10 & 3.75 & 2.36 \\
\hline $\mathrm{P}$ & 306 & 468 & 387 & $\mathrm{Ce}$ & 2.74 & 11.5 & 5.42 \\
\hline$S$ & 851 & 1510 & 1170 & $\operatorname{Pr}$ & 0.75 & 1.92 & 1.23 \\
\hline $\mathrm{Cl}$ & 4.27 & 14.6 & 9.01 & $\mathrm{Nd}$ & 4.81 & 13.9 & 9.24 \\
\hline $\mathrm{K}$ & 2030 & 3310 & 2920 & $\mathrm{Sm}$ & 0.68 & 1.43 & 1.08 \\
\hline $\mathrm{Ca}$ & $9.5 \%$ & $12.7 \%$ & $10.9 \%$ & $\mathrm{Eu}$ & 0.33 & 1.33 & 0.73 \\
\hline $\mathrm{Sc}$ & 0.76 & 2.76 & 1.93 & $\mathrm{Gd}$ & 0.53 & 3.13 & 1.63 \\
\hline $\mathrm{Ti}$ & 732 & 2930 & 1670 & $\mathrm{~Tb}$ & 0.12 & 2.20 & 0.64 \\
\hline V & 24.7 & 51.8 & 38.0 & Dy. & 0.56 & 1.23 & 0.80 \\
\hline $\mathrm{Cr}$ & 59.2 & 943 & 352 & Ho & 0.12 & 0.32 & 0.21 \\
\hline $\mathrm{Mn}$ & 165 & 274 & 231 & $\mathrm{Er}$ & 0.48 & 0.89 & 0.61 \\
\hline $\mathrm{Fe}$ & 5130 & 13700 & 9510 & $\mathrm{Tm}$ & 0.02 & 0.10 & 0.07 \\
\hline Co & 7.87 & 26.3 & 17.4 & $\mathrm{Yb}$ & 0.52 & 1.07 & 0.76 \\
\hline $\mathrm{Ni}$ & 19.8 & 46.5 & 37.5 & $\mathrm{Lu}$ & 0.04 & 0.12 & 0.09 \\
\hline $\mathrm{Cu}$ & 3.52 & 7.40 & 5.80 & Hf & 0.07 & 0.46 & 0.30 \\
\hline $\mathrm{Zn}$ & 6.10 & 27.2 & 15.6 & $\mathrm{Ta}$ & 0.15 & 1.72 & 0.43 \\
\hline $\mathrm{Ga}$ & 0.07 & 2.70 & 1.09 & W & 6.71 & 57.9 & 37.8 \\
\hline $\mathrm{Ge}$ & 0.06 & 2.45 & 0.89 & $\mathrm{Re}$ & $<0.01$ & 0.05 & 0.02 \\
\hline As & 0.02 & 0.68 & 0.33 & Os & 0.01 & 0.14 & 0.04 \\
\hline $\mathrm{Se}$ & $<0.01$ & 0.71 & 0.30 & Ir & $<0.01$ & 0.06 & 0.01 \\
\hline $\mathrm{Br}$ & 0.01 & 1.21 & 0.23 & $\mathrm{Au}$ & $<0.01$ & 0.24 & 0.10 \\
\hline $\mathrm{Rb}$ & 0.04 & 6.14 & 3.23 & $\mathrm{Pt}$ & 0.03 & 0.32 & 0.14 \\
\hline $\mathrm{Sr}$ & 0.03 & 344 & 187 & $\mathrm{Hg}$ & 0.09 & 1.75 & 0.85 \\
\hline$Y$ & 0.01 & 9.12 & 4.68 & $\mathrm{Tl}$ & 0.03 & 0.20 & 0.13 \\
\hline $\mathrm{Zr}$ & 0.02 & 37.1 & 20.2 & $\mathrm{~Pb}$ & 0.79 & 5.50 & 2.93 \\
\hline $\mathrm{Nb}$ & 0.01 & 5.18 & 1.62 & $\mathrm{Bi}$ & 0.01 & 0.07 & 0.04 \\
\hline Mo & 1.17 & 2.13 & 1.54 & Th & 0.01 & 0.82 & 0.42 \\
\hline $\mathrm{Ru}$ & 0.38 & 1.56 & 0.76 & $\mathrm{U}$ & 0.01 & 0.76 & 0.28 \\
\hline
\end{tabular}

* Results are given in weight parts per million except where noted as percentages. 


\section{NEUTRON ACTIVATION COMPARISONS}

To determine the effect of the gunite composition upon neutron activation, two indexes are used. First, the total activity of key radionuclides is compared. Second, the contact dose rate obtained using the expected gunite composition is compared to a volume-weighted average of the actual compositions.

\section{A. Activity Comparison}

Table III gives the total activity of key radionuclides as calculated using the expected and actual gunite compositions. Activities are given immediately following the last, $20 \mathrm{MJ}$ shot. Key radionuclides are defined as those that make at least a $1 \%$ contribution to the total contact dose rate at a time of 30 minutes or longer following the final shot.

Table III. Total activities of key radionuclides

\begin{tabular}{cccc}
\hline & \multicolumn{2}{c}{ Activity (Bq) } & Ratio (Actual/ \\
Nuclide & Expected & Actual & Expected) \\
\hline${ }^{22} \mathrm{Na}$ & $3.21 \mathrm{e} 8$ & $4.11 \mathrm{e} 8$ & 1.28 \\
${ }^{24} \mathrm{Na}$ & $2.38 \mathrm{e} 11$ & $3.48 \mathrm{e} 11$ & 1.46 \\
${ }^{27} \mathrm{Mg}$ & $1.27 \mathrm{e} 13$ & $1.93 \mathrm{e} 13$ & 1.52 \\
${ }^{47} \mathrm{Ca}$ & $8.13 \mathrm{e} 8$ & $7.41 \mathrm{e} 8$ & 0.91 \\
${ }^{46} \mathrm{Sc}$ & $9.37 \mathrm{e} 11$ & $5.57 \mathrm{e} 11$ & 0.59 \\
${ }^{48} \mathrm{Sc}$ & $3.93 \mathrm{e} 8$ & $5.77 \mathrm{e} 8$ & 1.47 \\
${ }^{54} \mathrm{Mn}$ & $1.10 \mathrm{e} 9$ & $1.32 \mathrm{e} 9$ & 1.20 \\
${ }^{56} \mathrm{Mn}$ & $4.58 \mathrm{e} 11$ & $5.19 \mathrm{e} 11$ & 1.13 \\
${ }^{59} \mathrm{Fe}$ & $1.03 \mathrm{e} 8$ & $1.29 \mathrm{e} 8$ & 1.26 \\
${ }^{60} \mathrm{Co}$ & $3.27 \mathrm{e} 9$ & $2.50 \mathrm{e} 9$ & 0.76 \\
${ }^{110 \mathrm{~m}} \mathrm{Ag}$ & $1.55 \mathrm{e} 8$ & $9.85 \mathrm{e} 7$ & 0.64 \\
${ }^{134} \mathrm{Cs}$ & $1.68 \mathrm{e} 8$ & $2.20 \mathrm{e} 8$ & 1.31 \\
${ }^{140} \mathrm{La}$ & $8.42 \mathrm{e} 8$ & $1.11 \mathrm{e} 8$ & 0.13 \\
${ }^{152} \mathrm{Eu}$ & $3.15 \mathrm{e} 9$ & $2.88 \mathrm{e} 9$ & 0.92 \\
${ }^{154} \mathrm{Eu}$ & $1.91 \mathrm{e} 8$ & $2.62 \mathrm{e} 8$ & 1.37 \\
${ }^{160} \mathrm{~Tb}$ & $2.36 \mathrm{e} 8$ & $3.00 \mathrm{e} 8$ & 1.27 \\
${ }^{182} \mathrm{Ta}$ & $2.37 \mathrm{e} 9$ & $1.64 \mathrm{e} 8$ & 0.07 \\
${ }^{187} \mathrm{~W}$ & $3.87 \mathrm{e} 10$ & $1.60 \mathrm{e} 10$ & 0.41 \\
\hline
\end{tabular}

Calculation of the actual activities correctly accounted for the position of each sample on the target chamber. The compositions applied on January 7 or January 10, for example, will be exposed to a significantly softer neutron spectrum than those applied on December 15-17, 1999.

In general, agreement between the expected and actual results is good. Several radionuclides of import to occupational doses, however, may be at levels higher than originally expected. For example, ${ }^{24} \mathrm{Na}$ (15 hour half-life) typically dominates the dose rate at decay times of relevance to many maintenance activities. The actual ${ }^{24} \mathrm{Na}$ activity in the NIF gunite is likely to be $46 \%$ higher than previously predicted based upon the second round of gunite testing. ${ }^{24} \mathrm{Na}$ is produced primarily via the ${ }^{27} \mathrm{Al}(\mathrm{n}, \alpha)$ reaction, but it is also made via the ${ }^{24} \mathrm{Mg}(\mathrm{n}, \mathrm{p})$ and ${ }^{23} \mathrm{Na}(\mathrm{n}, \gamma)$ reactions.

On the other hand, the long-lived radionuclides that tend to dominate the decommissioning dose (assumed to begin 3 years after the final shot) appear to have been accurately predicted or even overestimated. ${ }^{60} \mathrm{Co}(5.3$ year half-life) and ${ }^{152} \mathrm{Eu}$ (13.5 year half-life) should be produced at only $76 \%$ and $92 \%$ of the original estimated levels, respectively.

\section{B. Contact Dose Rate Comparison}

Contact dose rates that have been calculated using the expected and actual composition for the gunite shielding are reported in Figure 1. The figure also includes a plot of the contact dose rate using the actual composition divided by that using the expected composition. It is immediately obvious that the elements that are most important to the short-term ( $<$ hours) dose rate were predicted quite accurately. Those that are important for the mid-term (hours to days) dose rates, however, were underestimated. Finally, the radionuclides that are important for long-term ( $>$ days) dose rates were overestimated.

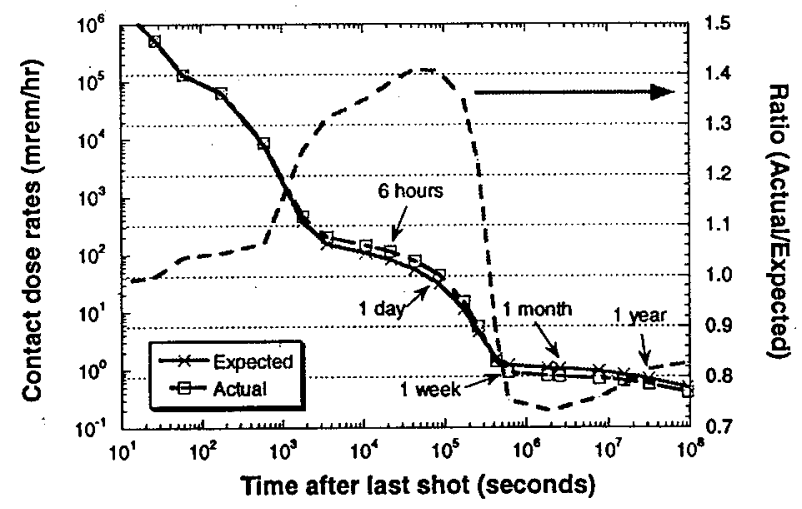

Fig. 1. Contact dose rates were accurately predicted in the short-term, underestimated in the mid-term, and overestimated in the long-term.

\section{Effect Upon Occupational Doses}

While significant variation in the gunite contact dose rate is predicted due to differences between the expected and actual elemental compositions, this does not necessarily imply that there will also be significant variation in the occupational dose rate near the target chamber. Figure 2 is a plot of the total dose rate at the back surface of the gunite shielding. It is worth noting that this is not a contact dose rate but a dose equivalent rate that has been calculated using gamma-ray transport 
to locations where a worker might be standing. Gammaray fluence-to-dose conversion factors have been used as prescribed by the American Nuclear Society. ${ }^{4}$ As shown in the plot, the gunite shielding typically contributes only $6-8 \%$ to the total dose rate near the target chamber.

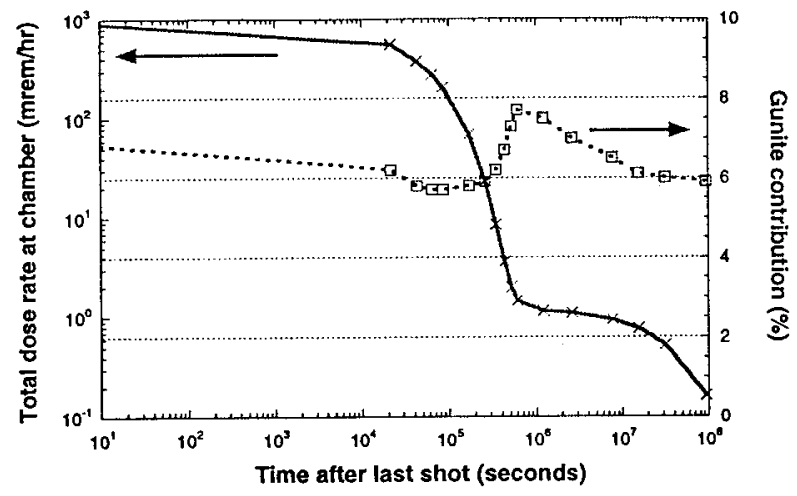

Fig. 2. Contributions from the gunite shielding account for only $6-8 \%$ of the total dose rate near the chamber.

In previous work, the effect of the actual target chamber aluminum alloy composition was discussed. ${ }^{5}$ If one recalculates the total dose rates using both the target chamber and gunite contact dose rate ratios, a new value for the total dose rate is obtained. Figure 3 is a plot of the original and updated total dose rates; the updated values account for the measured compositions of the target chamber and gunite shielding. Also plotted is the ratio of the updated to original total dose rate. As is evident from the figure, the original and updated total dose rates track quite well-the deviation never exceeds $\sim 2.5 \%$.

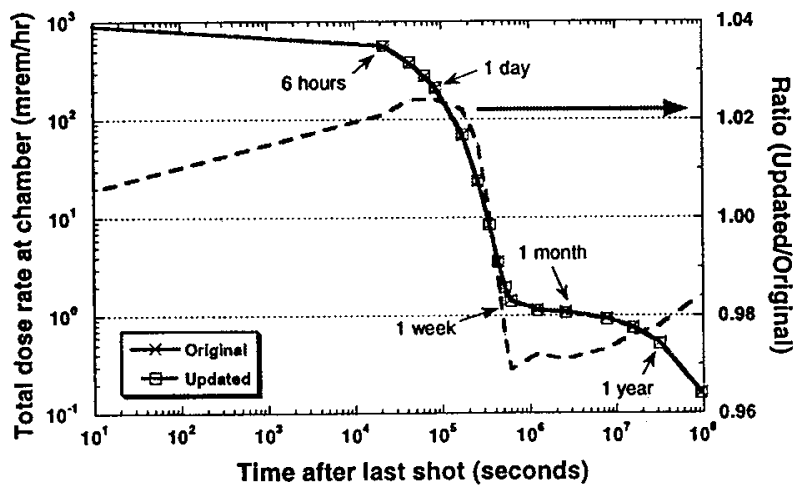

Fig. 3. Using contact dose rate scaling factors for contributions from the target chamber and gunite shielding, an updated value of the total dose rate near the chamber is obtained.

\section{CONCLUSIONS AND FUTURE WORK}

In the present work, measurements of the elemental compositions of the gunite shielding, which was applied to the exterior surface of the NIF target chamber, have been used to modify previously completed neutron activation calculations. Dose rate calculations have been updated using the true compositions, and the effects have been shown to be minimal (2-3\% deviation).

Future work will include the elemental analysis of the final optics assembly structures. These components are to be constructed of aluminum alloys 5083 and 6061, and they are the single-largest contributor to the total dose rate near the target chamber. Additionally, compositions will be measured for other key components on an as-needed basis.

\section{ACKNOWLEDGEMENTS}

Work performed under the auspices of the U. S. Department of Energy by University of California Lawrence Livermore National Laboratory under Contract W-7405-Eng-48. The author would like to thank Dick Wavrik of Sandia National Laboratory for making samples available. Additional thanks to Ron Pletcher and Joe Menapace of Lawrence Livermore National Laboratory who were responsible for the sample preparation and analysis, respectively. Funding for this work analyses was provided by the NIF Assurance Managers (Jon Yatabe and Sandra Brereton).

\section{REFERENCES}

[1] D. E. Cullen, TART98: a coupled neutron photon, 3$\mathrm{D}$, combinatorial geometry, time dependent, Monte Carlo transport code, Lawrence Livermore National Laboratory, UCRL-ID-126455, Rev. 2 (Nov. 1998).

[2] J. Sanz, ACAB98: Activation code for fusion applications. User's manual V4.0, Universidad Nacional de Educacion a Distancia, Lawrence Livermore National Laboratory, UCRL-CR-133040 (Feb. 1999).

[3] A.B Pashchenko, H. Wienke, J. Kopecky, J.-CH Sublet and R.A. Forrest, FENDL/A-2.0 neutron activation cross-section data library for fusion applications, International Atomic Energy Agency, IAEA-NDS-173 (Mar. 1997).

[4] American National Standard, "Neutron and gammaray fluence-to-dose factors," ANSI/ANS-6.1.1-1991, American Nuclear Society, La Grange Park, IL, 1991.

[5] J. F. Latkowski and J. Sanz, "Elemental ANalysis of As-Built Concrete and Aluminum for the National Ignition Facility and Their Effect upon Residual Dose Rates," Proceedings of the First International Conference on Inertial Fusion Sciences and Applications, Bordeaux, France 858 (Sep. 1999). 